\title{
Financing public capital when rents are back: a macroeconomic Henry George Theorem
}

\author{
Linus Mattauch, Jan Siegmeier, Ottmar Edenhofer, Felix Creutzig
}

January 30, 2018

\begin{abstract}
By taxing rents, governments can avoid a trade-off between productivityenhancing public investment and efficiency losses from raising funds. However, it is unclear whether the rents present in a growing economy are sufficient to finance its socially optimal level. We prove that the social optimum can be attained if the income share from a fixed factor, such as land, exceeds the public investment requirement. We thus translate the Henry George Theorem from urban economics to neoclassical and endogenous growth settings: here, the socially optimal land rent tax rate is below $100 \%$. Our finding may address the underfunding of national infrastructure investments.
\end{abstract}

JEL classification: $\mathrm{H} 21, \mathrm{H} 54, \mathrm{Q} 24$

Keywords: land rent, public investment, infrastructure, Henry George Theorem, optimal growth

\footnotetext{
*Mattauch: Institute for New Economic Thinking at the Oxford Martin School and Environmental Change Institute, School of Geography and the Environment, University of Oxford and Mercator Research Institute on Global Commons and Climate Change, Eagle House, Walton Well Road, OX2 6ED Oxford, United Kingdom. (linus.mattauch@inet.ox.ac.uk). Siegmeier: Mercator Research Institute on Global Commons and Climate Change, Torgauer Strasse 12-15, D-10829 Berlin, Germany. (siegmeier@mcc-berlin.net). Edenhofer: Mercator Research Institute on Global Commons and Climate Change, Technical University of Berlin and Potsdam Institute for Climate Impact Research, Torgauer Strasse 12-15, D-10829 Berlin (ottmar.edenhofer@pikpotsdam.de). Creutzig: Mercator Research Institute on Global Commons and Climate Change and Technical University of Berlin. Torgauer Strasse 12-15, D-10829 Berlin (creutzig@mcc-berlin.net). We thank Blanca Fernandez Milan, Max Franks and Gregor Schwerhoff for useful comments. Financial support from the Michael-Otto-Stiftung for the Chair Economics of Climate Change at TU Berlin is gratefully acknowledged. Linus Mattauch thanks the German Academic Scholarship Foundation for financial support. His research was also supported by a postdoctoral fellowship of the German Academic Exchange Service (DAAD).
} 


\section{Introduction}

Rents are back as a potential source of public revenue. While the taxation of rents has always been recognised as efficient George, 1879/2006, Friedman, 1978; Mankiw, 2007), both the magnitude of the rents and their importance for understanding inequality has increased in recent years Stiglitz, 2015, 2016a). In particular, rents on non-reproducible factors such as land are a highly significant share of total economic output (Caselli and Feyrer, 2007). Approximately half of total wealth is embodied in housing; similarly, increases in wealth since 1950 are largely due to it (Piketty, 2014 , Ch. 3 and 4). Surging house prices are primarily explained by land prices, not construction costs (Knoll et al., 2017). Thus, not subdividing wealth into capital and rent results in mistaken policy implications for combating increasing inequality (Stiglitz, 2016b).

This raises the question whether the taxation of rents can contribute to financing public investment at the national scale and in dynamic contexts. Collecting tax revenue for providing productivity-enhancing public investment usually creates inefficient allocations through a trade-off (Barro, 1990 Barro and Sala-I-Martin, 1992). While public investment bolsters growth in productivity, distortionary taxation - required to finance public investments

- creates efficiency losses. As a result, public investment remains below the socially optimal level.

Such a trade-off does not exist when public capital is financed by rent taxation. However, it is unclear if rents stemming from various sources can be sufficient for financing public investment. In this article, we examine when the socially optimal level of public capital can be financed from fixed factors of production such as land. We prove that if the land rent is higher than the socially optimal level of public investment, taxing the rent and 
investing the revenue in public capital is a socially optimal policy.

Our result implies that the socially optimal tax need not be at a rate of $100 \%$, and we determine the exact tax rates for the long-run equilibrium. This contrasts with the 'Henry George Theorem' of local public finance (Arnott and Stiglitz, 1979, Arnott, 2004), which implies a $100 \%$ tax on land rents. Otherwise, our result can be considered a macroeconomic analogue to the original theorem, which has been applied in urban public economics only. To our knowledge, we are the first to obtain such relationships in a model of economic growth. The results of this article may thus be seen as a new starting point for addressing underfunding of public infrastructure Bom and Ligthart, 2014) on a national scale. They adhere to the 'generalized Henry George Principle' (Stiglitz, 2014): government expenditure should be financed by a class of taxes that do not impact efficiency as far as possible.

The present study hence links three earlier strands of literature: First, studies of land taxation in public finance have been centered on the question whether it is distortionary or not (Feldstein, 1977, Calvo et al., 1979, Edenhofer et al., 2015). The relationship between the land price, the land rent and the interest rate has been captured as a no-arbitrage condition in growth models (Feldstein, 1977; Burgstaller, 1994; Foley and Michl, 1999, Edenhofer et al., 2015). Our study adopts their treatment of the production factor land in a growth model.

Second, public investment is a key determinant of aggregate productivity and its financing options have been widely studied (Romp and De Haan, 2007: Irmen and Kuehnel, 2009). It is currently insufficiently provided (Bom and Ligthart, 2014). Public investment may take the form of infrastructure (Barro, 1990; Gramlich, 1994), research and development (Romer, 1990) or investment into human capital via education or the health system Glomm 
and Ravikumar, 1992, Bloom et al., 2004). Barro (1990), Futagami et al. (1993) and Turnovsky (1996, 1997, 2000) have all studied the financing of public capital in endogenous growth models, clarifying the welfare effects of different options. For instance, Turnovsky (1997) and Chatterjee and Ghosh (2011) reproduce the social optimum with tax-financed public investment; however they employ (politically infeasible) lump-sum taxes to balance the government budget. While the question of financing public capital on a national scale has thus been treated extensively, the role of land as a source of revenue for this has been hitherto ignored.

Third, in urban economics, the central result for local public finance is the Henry George Theorem, which states that local land rents equal expenditure on a local public good provided the population size is optimal Stiglitz, 1977; Arnott and Stiglitz, 1979; Arnott, 2004). A major consequence of the Henry George Theorem is that a single $100 \%$ land rent tax is sufficient to finance a local public good. It is based on a static relationship and has chiefly been applied in the context of urban economics. A dynamic Henry George Theorem has been introduced by $\mathrm{Fu}(2005)$ and Kawano (2012) for studying transition phenomena of cities. These authors extend the Henry George Theorem by considering the present value of future public investments and land rents under the usual condition of optimal population size in the urban context.

However, our extension of the Henry George Theorem translates the relationship to the question of macroeconomic public investment. The present article thus unites the three strands of literature in public finance described above. It provides an alternative to the well-explored approaches to financing national public investment. By considering rent taxation at a national scale, we introduce a different option that reproduces the socially optimal 
allocation of public investment without lump-sum taxation.

Our result differs from the Henry George Theorem of urban public finance and adds to the discussion of infrastructure financing at the macroeconomic scale for both a theoretical and a practical reason: First, at a theoretical level, it is unclear how much of the original theorem survives in the context of a national economy and a dynamic setting, which has to be tested in growth models. We find that the optimal public capital provision does not necessitate a $100 \%$ rent tax. However, it requires the assumption that the income share of land exceeds the required public investment. Further, while the model introduced below assumes that taxing land rents is non-distortionary, our results translate to settings in which it is distortionary, but beneficial (Feldstein, 1977; Edenhofer et al., 2015) 1 1 Second, at a practical level, even if land taxes are frequently used as a sub-national source of funds, the increasing importance of rents at the macroeconomic level suggests that taxing rents may be useful to finance national public investment projects. Our article reinforces this point by comparing data on rents and public investment.

We proceed as follows: we extend the neoclassical model of economic growth to include public capital and land as factors of production. In section 2 , we determine the socially optimal allocation and the corresponding decentralised equilibrium. In section 3, we first prove that rents from fixed factors such as land may be taxed to restore the social optimum, provided the land rent is sufficiently high. A specific criterion is then derived for the

\footnotetext{
${ }^{1}$ Rent taxes differ from lump-sum taxes. The reason is that rents stem from limited factors in production, so that there is a limit to how much funds as a share of total output can be raised by land taxation. Our article identifies conditions under which the rent taxes suffice for optimal public investment, while it would always be feasible with lumpsum taxes. Moreover, for the policy-relevant case of heterogeneous households, a land rent tax would be different from a lump-sum tax because households differ in their land holdings. An application to heterogeneous households is beyond the scope of this article, but see Edenhofer et al. (2015).
} 
case of a Cobb-Douglas production function. This also yields a formula for the corresponding tax rate, which differs for steady-state and endogenousgrowth regimes. In section 4, we discuss several possible extensions and modifications, regarding taxing profits instead of rents, alternative forms of public spending, technological progress and heterogeneous households. Section 5 highlights the empirical relevance of our result: we verify that the land rent may in fact be higher than the socially optimal public investment in many economies. Section 6 concludes.

\section{Model}

We first describe the structure of the economy and determine the socially optimal allocation as a benchmark for evaluating policy instruments. We then develop a decentralised version of the model.

Output $Y$ at time $t$ depends on a private and public capital stocks $K$ and $G$ as well as land $L$ :

$$
Y_{t}=F\left(K_{t}, G_{t}, L\right)
$$

The production function has the conventional properties that $F_{K}, F_{G}, F_{L}>$ 0 , but $F_{K K}, F_{G G}, F_{L L}<0$, where $F_{K}:=\mathrm{d} F / \mathrm{d} K\left(K_{t}, G_{t}, L\right)$ etc. Total land $L$ is constant over time. For simplicity it is assumed that all - available, equally fertile - land is used in production at no opportunity costs. Therefore the social planner seeks the optimal allocation of resources between private capital $K$ and public capital $G$.

Output is divided between consumption $C$ and investment into the two capital stocks, which have constant depreciation rates $\delta_{k}$ and $\delta_{g}$ respectively. The social planner chooses consumption $C$ and investment into public capital 
$I_{g}$ to maximise the welfare of an infinitely-lived representative household. Its instantaneous utility is isoelastic as is standard in growth theory (see e.g. Acemoglu, 2009, Ch.8) and given by $U(C)=\left(C^{(1-\eta)}-1\right) /(1-\eta)$. The elasticity of intertemporal substitution is given by $\frac{1}{\eta}$ with $\eta \neq 1$. The maximisation problem of the social planner is thus

$$
\begin{array}{ll} 
& \max _{C_{t}, I_{g t}} \int_{t=0}^{\infty} U\left(C_{t}\right) e^{-\rho t} d t \\
\text { s.t. } & \dot{K}_{t}=F\left(K_{t}, G_{t}, L\right)-C_{t}-I_{g t}-\delta_{k} K_{t} \quad \text { and } \\
& \dot{G}_{t}=I_{g t}-\delta_{g} G_{t} .
\end{array}
$$

Here $\rho$ is the pure rate of time preference. The maximisation problem is completed by initial conditions for $K_{0}$ and $G_{0}$. Solving it by standard optimal control theory yields a Keynes-Ramsey rule for $K$ and $G$ :

$$
\frac{\dot{C}_{t}}{C_{t}}=\frac{1}{\eta}\left[F_{K}\left(K_{t}, G_{t}, L\right)-\rho-\delta_{k}\right]
$$

and similarly

$$
\frac{\dot{C}_{t}}{C_{t}}=\frac{1}{\eta}\left[F_{G}\left(K_{t}, G_{t}, L\right)-\rho-\delta_{g}\right]
$$

which implies

$$
F_{K}\left(K_{t}, G_{t}, L\right)-\delta_{k}=F_{G}\left(K_{t}, G_{t}, L\right)-\delta_{g}
$$

The decentralised version of the economy consists of two stock markets for capital and land and one flow market for the final consumption good. We detail the role of the households, the firms and the government in turn.

The single representative household maximises its intertemporal utility 
$V=\int_{0}^{\infty} U\left(C_{t}\right) e^{-\rho t} \mathrm{~d} t$ subject to its budget constraint:

$$
\dot{K}_{t}+p_{t} \dot{L}+C_{t}=r_{t} K_{t}+\left(1-\tau_{t}^{l r}\right) l_{t} L-\tau_{t}^{l v} p_{t} L
$$

Here $p$ denotes the land sales price, $l$ the land rental price and $r$ the interest rate. Two types of taxes can be introduced: a land rent tax $\tau^{l r}$ or a land value $\operatorname{tax} \tau^{l v}$. Income from renting out capital and land as well as labour can be spent on consumption, invested in capital or used to (potentially) increase the amount of land assets. Initial conditions for $K_{0}$ and $G_{0}$ and a transversality condition ${ }^{2}$ are observed.

Since there is just one representative agent and total land is fixed, $\dot{L}=0$ in equation (7). Although total land is fixed and homogenous households do not actually trade land among them, it makes sense to introduce a stock and a flow market for land in the above way in order to obtain a price for the asset that is included in households' wealth. This is the standard approach to modelling markets with two assets of which one is fixed (Feldstein, 1977; Burgstaller, 1994). The reasons for following it in this article are, first, that the frequently employed land value tax (not just a land rent tax) shall be analysed. Second, when there are heterogeneous households, the interplay between a land rent and a land value crucially matters for our main result that financing public investment by rent taxation restores the social optimum (see Subsection 4.3 below as well as Edenhofer et al. (2015); Siegmeier et al. (2017, 2018) for further applications). The land price $p_{t}$ is thus the potential price at which land would be traded.

Solving the intertemporal control problem, the behaviour of the house-

${ }^{2}$ The appropriate transversality condition is:

$$
\lim _{t \rightarrow \infty}[K(t)+p(t) L] e^{-\xi(t)}=0 \quad \text { with } \quad \xi(t) \equiv \int_{0}^{t} r(\tilde{t}) \mathrm{d} \tilde{t} .
$$


hold is captured by two first-order conditions: First, a (no-)arbitrage condition

$$
r_{t}=\left(1-\tau_{t}^{l r}\right) \frac{l_{t}}{p_{t}}+\frac{\dot{p_{t}}}{p_{t}}-\tau_{t}^{l v}
$$

links the evolution of land price, land rental price and the interest rate. Solving this equation for $p_{t}$ would show that the land price is equal to the net present value of all future land rent income. Second, the Keynes-Ramsey Equation for the household is:

$$
\frac{\dot{C}_{t}}{C_{t}}=\frac{1}{\eta}\left(r_{t}-\rho\right)
$$

On the production side, we assume a single representative firm and consider a production function that exhibits constant returns in private factors only, that is in capital and land. This implies that the returns to public investment are "added on" to factor returns (as in Barro (1990); Turnovsky (1997, 2000)); public investment increases both the land and capital value implicitly ${ }^{3}$ Formally, this means that $F\left(K_{t}, G_{t}, L\right)=F_{K} K_{t}+F_{L} L$. In this setting both decreasing or constant returns to the total stock of private and public capital are possible, leading to either steady-state convergence or long-run endogenous growth, respectively. In section 3 we consider both cases.

The firm's profit maximisation problem thus is:

$$
\max _{K, L} F\left(K_{t}, L, G_{t}\right)-\tilde{r}_{t} K_{t}-l_{t} L
$$

\footnotetext{
${ }^{3}$ This would even be the case for a small country facing a fixed world interest rate: The fixed interest rate would change the shares of capitalisation of public investment in the production factors capital and land, but not yield full capitalisation in land only.
} 
with $\tilde{r}_{t}=r_{t}+\delta_{k}$. This yields the standard first-order conditions

$$
\begin{gathered}
\tilde{r}_{t}=F_{K}\left(K_{t}, L, G_{t}\right) \\
l_{t}=F_{L}\left(K_{t}, L, G_{t}\right) .
\end{gathered}
$$

The government finances the provision of the public capital stock $G$ with the tax revenue $T_{t}$ :

$$
\dot{G}_{t}=T_{t}-\delta_{g} G_{t} .
$$

Below we assume that the tax revenue stems entirely from taxing either land value or land rent only, depending on the case we analyse.

\section{Main result: A macroeconomic Henry George Theorem}

In a decentralised equilibrium with productive public investment, the social optimum can typically not be reproduced because the government is not able to mobilise enough funds for providing the optimal amount of public investment in a non-distortionary way. In this section we show, however, that the social optimum may still be reached if rents from fixed factors such as land are high enough. Specifically, we first prove that if the land value is sufficiently high, generating the required public revenue by taxing the land value or the land rent is socially optimal (proposition 1 and corollary 2). This holds for both transition phases and the long-run equilibrium. Second, we determine conditions for a Cobb-Douglas production function that indicate when the land rent actually is sufficiently high in the long run. These differ depending on whether there is steady-state convergence or a balanced growth path, depending on the production structure (proposition 
3 and 4 ).

Since the setting of the present analysis is a growth model, it is not the case that land owners acquire all the rents, as in the case of the original Henry George Theorem. Public investment increases the marginal productivities of both land and capital, so it is not fully capitalized in land only, but rather in the returns to all private production factors. This is reflected in the following results:

Proposition 1 (Macroeconomic Henry George Theorem). Suppose that public capital constitutes a positive externality and that production has constant returns to scale only in the private factors of production, capital and land, so that profits are zero. A land value tax allows reproducing the social optimum if the land value is sufficient to finance the socially optimal public investment at all times.

While in practice, it may be more feasible to tax land value, previous theoretical contributions have often focused on the land rent. The following shows the equivalence of the two options:

Corollary 2 (Land rent taxation). Suppose that public capital constitutes a positive externality and that production has constant returns to scale in the private factors of production, capital and land. A tax on land rent allows to reproduce the social optimum if the land rent is sufficiently high to finance the socially optimal public investment at all times.

Proof of proposition 1. The idea of proof is to show that the dynamical systems of the socially optimal allocation (equations (2/5) and the decentralised equilibrium (equations $(7,12$ ) are identical. Then, if the social planner and the decentralised equilibrium have the same initial level of both $K_{0}$ and $G_{0}$, the latter will reproduce the paths of the former. Below, the 
aggregate variables of the dynamical system representing the decentralised equilibrium are denoted by a superscript $M$ (for "market").

For a single land value tax $\tau_{t}^{l v}$, the tax revenue amounts to $T=\tau_{t}^{l v} p_{t} L$ and the budget constraint of the household (7) becomes

$$
\dot{K}_{t}^{M}+p_{t} \dot{L}+C_{t}^{M}=r_{t} K_{t}^{M}+l_{t} L-\tau_{t}^{l v} p_{t} L
$$

Recall that since there is just one representative agent and total land is fixed, $\dot{L}=0$ in equation $(7 a)$. Assume that the land value is sufficient to fully finance the optimal level of public investment: the government can set the tax $\tau_{t}^{l v} \in[0,1)$ such that

$$
T_{t}=\tau_{t}^{l v} p_{t} L=I_{g t}
$$

If the previous equation holds, then the path for the public capital stock $G_{t}$ will be identical in both dynamical systems, as

$$
\dot{G}_{t}=I_{g t}-\delta_{g} G_{t}
$$

and

$$
\dot{G_{t}^{M}}=\tau_{t}^{l v} p_{t} L-\delta_{g} G_{t}^{M}=I_{g t}-\delta_{g} G_{t}^{M}
$$

Substituting the first-order conditions of the firm 10 11 into equation $(7 a)$ and employing the assumption that the production function has constant returns to scale in the privately available production factors then implies that

$$
\dot{K}_{t}^{M}=F\left(K_{t}^{M}, G_{t}, L\right)-\delta_{k} K_{t}^{M}-I_{g} t-C_{t}^{M}
$$


and

$$
\frac{\dot{C}_{t}^{M}}{C_{t}^{M}}=\frac{1}{\eta}\left(F_{K}\left(K_{t}^{M}, G_{t}, L\right)-\rho-\delta_{k}\right) .
$$

This means that the respective social planner- and decentralised versions of the equations for consumption and capital accumulation are identical, which completes the proof.

Proof of corollary 2. Assume that the land rent is sufficient to fully finance the optimal level of the public good: the government can set the tax $\tau_{t}^{l r} \in$ $[0,1)$ such that

$$
T_{t}=\tau_{t}^{l r} l_{t} L=I_{g t}
$$

Similarly to the previous proof, it can be shown that if only land rents are taxed, the aggregate variables are at the socially optimal level, noting that the budget constraint of the household (7) becomes

$$
\dot{K}_{t}^{M}+p_{t} \dot{L}+C_{t}^{M}=r_{t} K_{t}^{M}+\left(1-\tau_{t}^{l r}\right) l_{t} L
$$

We now investigate the premise of proposition 1 and corollary 2 2 It is not guaranteed that the land rent is sufficient, that is, higher than the socially optimal public investment. For the specific case of a Cobb-Douglas function, we derive a sufficiency condition both for the steady state in a neoclassical growth setting and for the balanced growth path when there is endogenous growth. By the equivalences of proposition 1 and corollary 2 this also gives the socially optimal tax to be levied on land values. In Section 5, we check whether such formulae plausibly hold for most economies.

We distinguish two cases: first, we derive a "Macroeconomic Henry 
George Formula" (proposition 3) for the case of steady-state convergence, which occurs if the production function has decreasing returns to scale in accumulable factors, namely private and public capital. We subsequently analyse the case of constant returns to scale in accumulable factors, which yields proposition 4

Assume that there are decreasing returns to scale in accumulable production factors. For any initial capital stocks $\left(K_{0}, G_{0}\right)$ the economy converges to a (non-trivial and saddle-point stable) steady state $\left(K^{*}, G^{*}, C^{*}, I_{g}^{*}\right)$. In the steady-state, time-derivatives in equations (2,5) are zero. Hence the steady-state, for the social planner case, is characterised by:

$$
\begin{aligned}
F_{K}^{*}=F_{K}\left(K^{*}, G^{*}, L\right) & =\rho+\delta_{k} \\
F_{G}^{*}=F_{G}\left(K^{*}, G^{*}, L\right) & =\rho+\delta_{g} \\
F\left(K^{*}, G^{*}, L\right) & =C^{*}+I_{g}^{*}+\delta_{k} K^{*} \\
I_{g}^{*} & =\delta_{g} G^{*} .
\end{aligned}
$$

To obtain a relation between the optimal public investment $I_{g}^{*}$ and the land rent $R=F_{L} \cdot L$ in the steady state, assume that the production function has Cobb-Douglas form:

$$
F(K, G, L)=G^{\beta} K^{\alpha} L^{1-\alpha}
$$

(with $0<\alpha, \beta<1$ and $\alpha+\beta<1$ ), which implies

$$
F_{G}=\beta \frac{Y}{G} ; \quad F_{K}=\alpha \frac{Y}{K} ; \quad F_{L}=(1-\alpha) \frac{Y}{L} .
$$


The land rent $R$ is thus given by

$$
R=F_{L}(K, G, L) \cdot L=(1-\alpha) Y \text {. }
$$

Recall that only the private production factors are paid their marginal product, so that, nevertheless

$$
r K+l L=\alpha Y+(1-\alpha Y)=Y .
$$

Proposition 3 (Simple Macroeconomic Henry George Formula). Suppose production can be described by the Cobb-Douglas function given by equation (23). Then, in the steady state of the socially optimal allocation, the investment in public capital is related to the land rent as follows:

$$
I_{g}^{*}=\frac{\delta_{g}}{\rho+\delta_{g}} \frac{\beta}{1-\alpha} R
$$

So proposition 2 applies to the steady state of the neoclassical growth case if $\frac{\delta_{g}}{\rho+\delta_{g}} \frac{\beta}{1-\alpha}<1$ and the socially optimal land rent tax rate to be implemented by the government is $\tau=\frac{\delta_{g}}{\rho+\delta_{g}} \frac{\beta}{1-\alpha}$.

The result has the intuitive interpretation that if the national income share of land is greater than that of the public capital stock, the socially optimal investment in public capital is lower than the land rent (assuming that the first factor in equation (27) is approximately equal to one).

Proof. We exploit the steady state relationships. By equations 22 and 24 ,

$$
I_{g}^{*}=\delta_{g} \beta \frac{Y^{*}}{F_{G}^{*}}
$$


To eliminate $F_{G}^{*}$, equation 20 is used:

$$
I_{g}^{*}=\frac{\delta_{g}}{\delta_{g}+\rho} \beta Y^{*} .
$$

Inserting equation 25) yields the claimed formula.

Second, a similar formula can be derived for the balanced growth path in the case of endogenous growth ${ }^{4}$

Assume that the production function has constant returns to scale in the accumulable factors $K$ and $G$. Thus in the specification of the production function as Cobb-Douglas in equation (23) assume $\alpha+\beta=1$. For simplicity, we only consider the case $\delta:=\delta_{k}=\delta_{g}$. The socially optimal allocation converges to a balanced growth path, on which aggregate variables grow at the same rate:

$$
\frac{\dot{C}_{t}}{C_{t}}=\frac{\dot{K}_{t}}{K_{t}}=\frac{\dot{G}_{t}}{G_{t}}=g
$$

To obtain a formula for the common growth rate $g^{*}$ we use that, from equations (6) and (23),

$$
G_{t}=\frac{\beta}{1-\beta} K_{t}
$$

so that

$$
F_{K}\left(G_{t}, K_{t}, L\right)=F_{G}\left(G_{t}, K_{t}, L\right)=\frac{\beta^{\beta}}{(1-\beta)^{\beta-1}} L^{1-\alpha}
$$

Inserting this in equation (4) yields

$$
g^{*}=\frac{1}{\eta}\left(\frac{\beta^{\beta}}{(1-\beta)^{\beta-1}} L^{1-\alpha}-\rho-\delta\right) .
$$

\footnotetext{
${ }^{4}$ Note that, for simplicity, we do not consider a set-up with technological change (but see Subsection 4.4). This is in line with the literature on the growth effects of public capital (Turnovsky, 1997, 2000) and our term "endogenous growth" reflects the endogeneity through public investment, not technological change.
} 
The analogue of proposition 3 for the balanced path of the case of endogenous growth is as follows:

Proposition 4 (Macroeconomic Henry George Formula for the endogenous growth case). Suppose production can be described by the Cobb-Douglas function given by equation (23) with $\alpha+\beta=1$. Then, on the balanced growth path of the socially optimal allocation, the investment in public capital is related to the land rent as follows:

$$
I_{g t}=\frac{\left(\delta+g^{*}\right)}{F_{G}} \frac{\beta}{1-\alpha} R_{t}
$$

where $F_{G}$ is constant with the value given in equation (32). So corollary 2 holds if $\frac{\left(\delta+g^{*}\right)}{F_{G}} \frac{\beta}{1-\alpha}<1$ and the socially optimal land rent tax rate to be implemented by the government is $\tau_{t}=\frac{\left(\delta+g^{*}\right)}{F_{G}} \frac{\beta}{1-\alpha}<1$.

As in the case of neoclassical growth, the socially optimal allocation can be reached if the two fractions are smaller than 1 . In particular, this is true if the national income share of land is greater than that of the public capital stock and

$$
\frac{\left(\delta+g^{*}\right)}{F_{G}}<1
$$

By inserting equation (33), it can be verified that this inequality is true for all $\eta \geq 1-\frac{\rho}{F_{G}-\delta}$, so in particular for all $\eta \geq 1$.

Proof. The proof is similar to that of the previous proposition. From equation (3), it follows that for the case of endogenous growth, $I_{g t}=\left(g^{*}+\delta\right) G_{t}$. The formula is then obtained by combining the equations for the factor shares for $G_{t}$ and the land rent $R_{t}$ and inserting equation (32).

Finally, if fixed factor rents are lower than the optimal public investment, it may still be beneficial that the government obtains more funds for public 
investment through levying another tax, such as a distortionary labour income tax, which we do not model here. Of course the usual trade-off between productivity-enhancing investment and distortionary taxation Barro, 1990 Turnovsky, 2000; Chatterjee and Turnovsky, 2012; Klenert et al., 2016) then applies again for that part of the investment need that exceeds the land rent.

\section{Robustness and extensions}

We consider the following extensions and modifications of our results on taxing the factor land. First, we analyse a version of our model with profits to elaborate on the analogy to the original Henry George Theorem. Second, we show that our main result is robust with respect to alternative formulations of government spending. Third, the result also holds for household heterogeneity and trade on stock markets. Fourth, we delineate the role of labour- and land-augmenting exogenous technological progress.

\subsection{The macroeconomic Henry George Theorem when firms make profits from public investment}

The simplest version of the Henry George Theorems of local public finance, proved by Stiglitz (1977), considers decreasing returns in labor due to limited space in a local economy, so that firms make profits. In this setting, profits can thus be seen as a special case of land rents. It is then socially optimal to use the entire profit in a static urban economy to finance a local utilityenhancing public good, provided the population size is optimal (see also Atkinson and Stiglitz, 1980 , p. 522-525). We translate the mechanism to a growth model in which the public and the private capital stocks are optimal.

We assume in this subsection that public capital creates a positive externality in production that yields profits in a growing economy, with decreasing 
returns to scale in private factors. We then prove that if a society generates rents by public investment in this way, the social optimum can always be implemented by taxing these rents in the long run. However, because of the dynamic context, the pure rate of time preference causes the rent to be higher than the required optimal public investment in the steady state, that is, taking away less than $100 \%$ is always sufficient to establish the social optimum in the long run.

Unlike profits arising from a source of market power, profits in this case are a consequence of introducing public capital $G$ in production in a way that affects all firms alike and without congestion. It can hence be modelled as profits of a representative firm. This may be a credible assumption for some forms of public investments, such as technology parks. However, the focus of this section is the close kinship of our results with the original Henry George Theorem, not on exploring which assumptions concerning the impact of public investments on the economy are most realistic. We hence abstract from the exact origins of the production function, barriers to market entry and the number of firms in the market, or the potential for and prevention of market power.

To see the result, assume that the production function exhibits constant returns in all factors of production. Public investment will generate profits in the decentralised case, but the long-run outcome can only be a steady state. The value of the public investment fully materialises as firms' profits. Profit maximisation then implies not only factor prices given by equations (10) and (11), but also that the representative firm makes profits given by:

$$
\Pi_{t}=F\left(K_{t}, G_{t}, L\right)-\tilde{r}_{t} K_{t}-l_{t} L=F_{G}\left(K_{t}, \bar{S} ; G_{t}\right) G_{t} .
$$


We prove that financing public expenditure by taxing profits is socially optimal if profits are higher than the socially optimal public investment, both in the steady state and the transitional dynamics of the model. We show that in the steady state they are always sufficient. (We therefore assume that other taxes are set to zero.)

Proposition 5 (Macroeconomic analogue of Stiglitz' (1977) Henry George Theorem). Assume production has constant returns to scale in all inputs: public capital, private capital and land. The social optimum can be implemented by taxing firms' profits, if these are higher than the socially optimal investment. In the steady state, taxing profits is always sufficient: The optimal tax rate on profits is $\tau^{p}=\frac{\delta_{g}}{\delta_{g}+\rho}$.

In Stiglitz' (1977) result, $\tau^{p}=1$. In our dynamic setting a non-zero rate of pure time preference $\rho$ causes $\tau^{p}<1$. This reflects that in neoclassical growth models the optimal capital stock does not maximise instantaneous consumption.

Proof. Similarly to the proof of proposition 1, it can be shown that if only profits are taxed, the aggregate variables are at the socially optimal level, noting that with a tax on profits, tax revenue is $T_{t}=\tau_{t}^{p} \Pi_{t}$ and the budget constraint of the household (7) becomes

$$
\dot{K}_{t}+p_{t} \dot{L}+C_{t}=r_{t} K_{t}+l_{t} L+\left(1-\tau_{t}^{p}\right) \Pi_{t} .
$$

This part assumes that profits are sufficient to fully finance the optimal level of the public good: the government can set the tax $\tau_{t}^{p} \in[0,1)$ such that

$$
T=\tau_{t}^{p} \Pi_{t}=I_{g t}
$$


For the second part of the proposition, note that the steady state, for the social planner case, is still characterised by equations 19.22 , even with the modified production structure.

Thus, by equation (20), the equivalent of profits in the social optimum is given by:

$$
\Pi_{t}^{*}=F_{G}\left(K^{*}, G^{*}, L\right) G^{*}=\left(\delta_{g}+\rho\right) G^{*} .
$$

Combining equations (22), (37) and (38) yields

$$
\tau^{p}\left(\delta_{g}+\rho\right) G^{*}=\delta_{g} G^{*}
$$

Hence

$$
\tau^{p}=\frac{\delta_{g}}{\delta_{g}+\rho}<1
$$

which establishes that profits always suffice to restore the social optimum in the steady state.

\subsection{Alternative models of government spending}

Alternative formulations of government expenditure besides investing into a productive public capital stock have been extensively considered in public economics, for instance productive government flow expenditure or investment into utility-enhancing public or private goods, which each may or may not be congestible (Barro and Sala-I-Martin, 1992, Turnovsky, 1997; Irmen and Kuehnel, 2009). We limit our discussion to the cases of, first, the public capital stock entering the utility function instead of the production function and second, the difference between investment in a public capital stock and productive government flow expenditure.

Concerning the first variant, assume that government expenditure pro- 
vides private goods entering the individuals' utility function. In the decentralised model, the households' and firms' optimisation problem remains virtually unchanged since $G$ only appears in the utility function and disappears from the production function, but does not become a control variable. Thus, it can be shown that proposition 1 still holds.5

For the second case, it can be shown that the findings of this study are all valid regardless of whether the productive public good is formulated as a stock (to which the government expenditure continuously adds) or flow (equal to government expenditure). However, the stock formulation seems preferable as we are chiefly concerned with productivity-enhancing public expenditure such as infrastructure provision. Considering a public capital stock is also more convenient for further empirical analyses: as shown below, it is plausible that in developed economies land rents are sufficient to finance what is generally defined as public investment up to the socially optimal level (see Section 5) - but it is doubtful that they can additionally cover the much broader category of government flow spending.

\subsection{Stock markets and household heterogeneity}

Our main result is robust with respect to under-accumulation, but not overaccumulation of private capital. Analysing the dynamics of stock markets for fixed factors of production, such as land, with the neoclassical growth model has severe limitations (Feldstein, 1977, Burgstaller, 1994): land will not be traded as the continuum of homogenous agents own an equal share of land, but have neither an incentive nor a trade partner to buy or sell any of it. Land thus exhibits 'partial equilibrium' properties. Taxing its rent is non-

\footnotetext{
${ }^{5}$ No simple proportionality between optimal government expenditure and land rent as in proposition 3 or 4 can be derived, since there is no direct link between the public good and land via the production function anymore.
} 
distortionary and the tax falls entirely on the owners of land, although this is not the case in more general circumstances of over- or under-accumulation (Feldstein, 1977). There is in particular no rebalancing of households' savings portfolios: households have no incentive to invest more in capital when a land rent tax is introduced. Edenhofer et al. (2015) explore, by means of a continuous overlapping generations model, the social optimality of land rent taxation when heterogeneous households acquire more land as they get older. In such a model, which exhibits suboptimal capital accumulation, when land is taxed, households invest into other assets, notably private capital. Thus land rent taxation is distortionary, but beneficial. The results of the present study can be reproduced in such a framework with some minor modifications due to the demographic structure. More generally, as long as the unregulated equilibrium exhibits under-accumulation in private capital the conclusions of the present study hold in frameworks in which such a "macroeconomic portfolio effect" exists. However, if over-accumulation prevails in an economy, this effect may create again a trade-off between the welfare loss caused by the land tax and the benefits from public investment.

\subsection{Labour- and land-augmenting technological progress}

With technological progress and additionally introducing the production factor 'labor', the main results of this article hold as long as the economy is on a balanced growth path, given decreasing returns to accumulation of producible factors. Such a path can exist if and only if productivity growth in land equals productivity growth in labour (including population growth). If the economy is not on the balanced growth path, the factor share of land may change over time, depending on the production function. The feasibility of the social optimum depends on the factor shares according to proposition 
3. outside the balanced growth path an increasing factor share accruing to land makes reaching the social optimum more likely. For example, for the case of a CES production function with substitution elasticity $\sigma$, the factor share accruing to land grows faster than the factor share accruing to labour if and only if either $\sigma>1$ and productivity growth in land is greater than that in labour or $\sigma<1$ and labour productivity growth is greater than that in land 6

\section{Empirical relevance}

Here we compare data on public investment needs and non-producible factor income. We find that in practice, fixed factor rents often exceed funding needs for public capital stocks considered here, and are thus highly relevant for financing government expenditure in general. Figure 1 illustrates this by reproducing actual public investment shares and non-producible factor income shares for 25 (mostly OECD) countries. We summarise some empirical findings, first on public investment needs and then on rents.

Regarding the investment needs of industrialised countries, maintaining the infrastructure and adapting it to the challenges of climate change Davis et al. 2010) translates into significant shares of government spending: The OECD reports public investment shares averaged over 2006 to 2011 for 34 countries that range between $1.1 \%$ (Austria) and $5.22 \%$ (South Korea) of GDP. The investment needs in poorer countries are highlighted by data from

\footnotetext{
${ }^{6}$ George, 1879/2006, bk. 4, ch. 1 and bk. 6 ch. 2) claimed that the factor share accruing to land grows faster than that accruing to labour. While this is not possible in the steady state or under a Cobb-Douglas production function in general, outside a balanced growth path Henry George's claim about the role of the land rent may be true. In particular the condition that $\sigma<1$ and productivity growth in labour was greater than in land seems to have some plausibility for economic development in the $19^{t h}$ century. It is less plausible for current developed economies, for which it may be supposed that $\sigma>1$, but still that labour productivity grows faster than land productivity.
} 


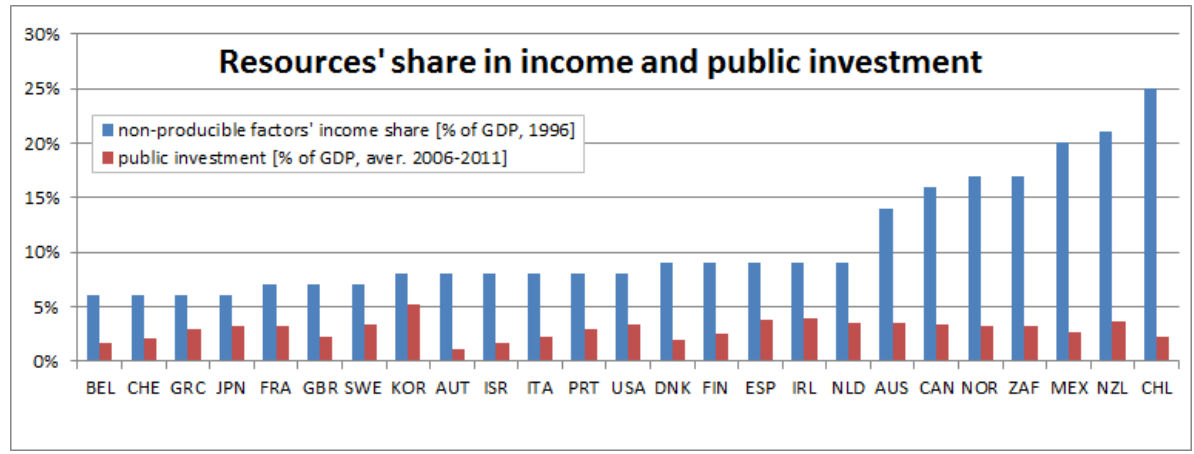

Figure 1: Income shares of non-producible factors (Caselli and Feyrer, 2007) and public investment (OECD, 2013a), ISO3 country codes.

the World Bank (2009) showing that access to basic utility services such as water, sanitation and electricity in low-income countries was $65 \%, 36 \%$ and $23 \%$, respectively, and still only $92 \%, 72 \%$ and $97 \%$ for upper-middle income countries. Estache and Fay (2009) estimated overall infrastructure investment and maintenance expenditure needs between 2005 and 2015 for low, lower-middle and upper-middle income countries to be 7.5, 6.3 and 3.1 percent of GDP, respectively, just to meet increasing demand due to projected growth. While these figures may not be optimal by some welfare criterion, they indicate the order of magnitude and the larger public investment needs in poorer countries lacking the most basic infrastructure.

Regarding the fixed factor rents, Caselli and Feyrer (2007) estimate income shares of non-producible factors such as land and natural resources for the year 1996 for 51 countries and find values ranging from 6\% in Belgium to $47 \%$ in Ecuador, with a median of $14 \%$. Also, non-producible factors tend to be more important for poorer countries. We do not have data that permit to isolate the income share of land across different countries. However, Caselli and Feyrer (2007) use "Proportions of different types of wealth in total wealth" (p.547) to show that land wealth is relatively more important in most cases: although subsoil resources matter for some countries and the 
mean wealth share is $10.5 \%$ (with a standard deviation of 16.4 ), the mean share of land-related wealth is at $34.8 \%$. The median wealth share of subsoil resources is only $1.5 \%$; compared to a $23.5 \%$ median share of land-related wealth. Moreover, the data set of that study excludes countries in which fossil fuel extraction is a main income source, such as countries on the Arabic Peninsula.

These figures may change slowly over time (note that the diagram plots data from 2006-2011 and 1996). However, the significant gap between fixedfactor income shares and public investment persists across structurally very different economies: even the lowest fixed-factor income, $6 \%$ for Belgium, is higher than the highest public investments, $5.22 \%$ for Korea. Overall, this indicates that fixed factor rents can be assumed to be of a magnitude that is at least comparable to that of infrastructure spending needs.

In our view, a treatment of actually levied property taxes does not help to clarify the empirical relevance as our contribution makes the point that land rent taxes in principle suffice to finance optimal public investment. Most countries currently levy property taxes, not taxes on the unimproved value of land (Dye and England, 2009, Fernandez Milan et al., 2016). Data on property taxes (OECD, 2013b) alone do not allow for a meaningful estimation of the share of national output accruing to fixed factors. However, a recent empirical study confirms that land taxes provide a large untapped potential for financing infrastructures for sustainable development, but require consistent land registry and adequate representation of historically grown informal use rights (Kalkuhl et al. 2017). 


\section{Conclusion}

Imagine a national infrastructure commission is to devise proposals on how to finance the current gap in funding of public investment. A standard answer from economic theory is that whenever rents exist, a tax on rents is the best way of generating revenue. However, it has neglected the question of when rents are actually sufficient for optimal public investment at the macroeconomic level. This study thus determines when macroeconomic public investment can be financed optimally by a tax on rent. We show that it is possible to reach the social optimum by taxing away less than $100 \%$ of the rents from fixed factors such as land. This is the case if land contributes more to output than public investment. Our results can be seen as a macroeconomic analogue of the Henry George Theorem from urban public finance: the socially optimal public investment can be financed by taxing rents. The theoretical results of this study are robust with respect to a variety of different assumptions: (i) neoclassical growth (both short- and long-run) or an endogenous growth regime, (ii) profit-generating public investment if profits can be taxed, (iii) utility-enhancing public capital or government flow spending, (iv) under-accumulation in private capital and (v) technological progress in land and labour compatible with balanced growth. It was verified that for OECD countries, land rents are significantly higher than current public investment. Hence, our results suggest an empirically sound financing mechanism for national public investment needs.

\section{References}

Acemoglu, D., 2009. Introduction to modern economic growth. Princeton University Press.

Arnott, R. J., 2004. Does the Henry George Theorem provide a practical guide to optimal city size? American Journal of Economics and Sociology 63(5), 1057-1090.

Arnott, R. J., Stiglitz, J. E., 1979. Aggregate land rents, expenditure on public goods, and optimal city size. Quarterly Journal of Economics 93(4), 471-500. 
Atkinson, A. B., Stiglitz, J. E., 1980. Lectures on public economics. McGraw-Hill.

Barro, R. J., 1990. Government spending in a simple model of endogenous growth. Journal of Political Economy 98(5), 103-125.

Barro, R. J., Sala-I-Martin, X., 1992. Public finance in models of economic growth. The Review of Economic Studies 59(4), 645-661.

Bloom, D. E., Canning, D., Sevilla, J., 2004. The effect of health on economic growth: theory and evidence. World Development 32(1), 1-13.

Bom, P. R. D., Ligthart, J. E., 2014. What have we learned from three decades of research on the productivity of public capital? Journal of Economic Surveys 28(5), 889-916.

Burgstaller, A., 1994. Property and prices: Toward a unified theory of value. Cambridge University Press.

Calvo, G. A., Kotlikoff, L. J., Rodriguez, C. A., 1979. The incidence of a tax on pure rent: A new (?) reason for an old answer. Journal of Political Economy 87(4), 869-874.

Caselli, F., Feyrer, J., 2007. The marginal product of capital. Quarterly Journal of Economics $122(2), 535-568$.

Chatterjee, S., Ghosh, S., 2011. The dual nature of public goods and congestion: the role of fiscal policy revisited. Canadian Journal of Economics 44(4), 1471-1496.

Chatterjee, S., Turnovsky, S. J., 2012. Infrastructure and inequality. European Economic Review 56(8), 1730-1745.

Davis, S. J., Caldeira, K., Matthews, H. D., 2010. Future CO2 emissions and climate change from existing energy infrastructure. Science 329(5997), 1330-1333.

Dye, R. F., England, R. W., 2009. Land value taxation: theory, evidence, and practice. Lincoln Institute of Land Policy.

Edenhofer, O., Mattauch, L., Siegmeier, J., 2015. Hypergeorgism: When rent taxation is socially optimal. FinanzArchiv/Public Finance Analysis 71(4), 474-505.

Estache, A., Fay, M., 2009. Current debates on infrastructure policy. Commission on Growth and Development. Working Paper 49.

Feldstein, M. S., 1977. The surprising incidence of a tax on pure rent: A new answer to an old question. Journal of Political Economy 85(2), 349-360.

Fernandez Milan, B., Kapfer, D., Creutzig, F., 2016. A systematic framework of location value taxes reveals dismal policy design in most european countries. Land Use Policy $51,335-349$.

Foley, D. K., Michl, T. R., 1999. Growth and Distribution. Harvard University Press.

Friedman, M., 1978. Unsigned news article. http://www.cooperativeindividualism. org/friedman-milton_interview-1978.html, retrieved: 15-02-08. [Reprinted from: The Times Herald, Norristown, Pennsylvania; Friday, 1 December, 1978].

Fu, S., 2005. Essays on urban agglomeration economies. Ph.D. thesis, Boston College.

Futagami, K., Morita, Y., Shibata, A., 1993. Dynamic analysis of an endogenous growth model with public capital. The Scandinavian Journal of Economics 95, 607-625. 
George, H., 1879/2006. Progress and Poverty. An inquiry into the cause of industrial depressions and of increase of want with increase of wealth. The Remedy. Elibron Classics, reprint of the 1894 edition.

Glomm, G., Ravikumar, B., 1992. Public versus private investment in human capital: endogenous growth and income inequality. Journal of Political Economy 100(4), 818834 .

Gramlich, E. M., 1994. Infrastructure investment: a review essay. Journal of Economic Literature 32, 1176-1196.

Irmen, A., Kuehnel, J., 2009. Productive government expenditure and economic growth. Journal of Economic Surveys 23(4), 692-733.

Kalkuhl, M., Fernandez Milan, B., Schwerhoff, G., Jakob, M., Hahnen, M., Creutzig, F., 2017. Fiscal instruments for sustainable development: The case of land taxes. MPRA Working Paper No. 78652.

Kawano, M., 2012. Henry George Theorem in a dynamic framework without accumulation of public goods. Kwansei Gakuin University School of Economics Discussion Paper 92.

Klenert, D., Mattauch, L., Edenhofer, O., Lessmann, K., 2016. Infrastructure and inequality: Insights from incorporating key economic facts about household heterogeneity. Macroeconomic Dynamics, online first. doi:10.1017/S1365100516000432 .

Knoll, K., Schularick, M., Steger, T., 2017. No price like home: Global house prices, 1870-2012. American Economic Review 107(2), 331-353.

Mankiw, G. N., 2007. Principles of Economics. International Student Edition. Thomson South-Western, 4th edition.

OECD, 2013a. Economic policy reforms: Going for growth 2013. Policy report, table "Public investment: Percentage of GDP", DOI:http://dx.doi.org/10.1787/growth2013-graph177-en, retrieved 2013/04/09.

OECD, 2013b. Tax on property, oecd data. https://data.oecd.org/tax/ tax-on-property.htm, [Retrieved 16-06-01].

Piketty, T., 2014. Capital in the Twenty-first Century. Harvard University Press.

Romer, P. M., 1990. Endogenous technological change. Journal of Political Economy 98(5), S71-S102.

Romp, W., De Haan, J., 2007. Public capital and economic growth: A critical survey. Perspektiven der Wirtschaftspolitik 8(S1), 652.

Siegmeier, J., Mattauch, L., Edenhofer, O., 2018. Capital beats coal: How collecting the climate rent increases aggregate investment. Journal of Environmental Economics and Management, in press .

Siegmeier, J., Mattauch, L., Franks, M., Klenert, D., Schultes, A., Edenhofer, O., 2017. The fiscal benefits of stringent climate change mitigation: an overview. Climate Policy, online first. Doi: 10.1080/14693062.2017.1400943 .

Stiglitz, J., 1977. The theory of local public goods. In: Feldstein, M., Inman, R. (Eds.), The Economics of Public Services, MacMillan, London. 
Stiglitz, J. E., 2014. Reforming taxation to promote growth and equity. Roosevelt Institute, White Paper.

Stiglitz, J. E., 2015. The origins of inequality and policies to contain it. National Tax Journal 68(2), 425-448.

Stiglitz, J. E., 2016a. How to restore equitable and sustainable economic growth in the united states. American Economic Review 106(5), 43-47.

Stiglitz, J. E., 2016b. New Theoretical Perspectives on the Distribution of Income and Wealth Among Individuals. In: Basu, K., Stiglitz, J. E. (Eds.), Inequality and Growth: Patterns and Policy, Volume I: Concepts and Analysis, IEA Conference Volume No. 156-I, Houndmills, UK and New York: Palgrave Macmillan.

Turnovsky, S. J., 1996. Optimal tax, debt, and expenditure policies in a growing economy. Journal of Public Economics 60(1), 21-44.

Turnovsky, S. J., 1997. Fiscal policy in a growing economy with public capital. Macroeconomic Dynamics 1, 615-639.

Turnovsky, S. J., 2000. Fiscal policy, elastic labor supply, and endogenous growth. Journal of Monetary Economics 45(1), 185-210.

World Bank, 2009. World development indicators 2009. database, available at http://databank.worldbank.org/data/views/variableselection/ selectvariables.aspx?source=world-development-indicators, retrieved 2013/03/25.

\section{A Derivations of control problems: NOT for pub- lication, but may be an online appendix if de- sired by journal}

Social planner Writing $\lambda$ and $\mu$ for the multipliers of (2) and (3) in the (current value) Hamiltonian $H$, we obtain the following first order conditions (dropping the $t$ subscripts):

$$
\begin{aligned}
& \frac{\partial H}{\partial C}=U_{C}-\lambda=0 \\
& \frac{\partial H}{\partial I_{g}}=\mu-\lambda=0 \\
& \rho \lambda-\dot{\lambda}=\frac{\partial H}{\partial K} \Rightarrow \\
& \dot{\lambda}=\lambda\left(-F_{K}+\delta_{k}+\rho\right) \\
& \rho \mu-\dot{\mu}=\frac{\partial H}{\partial G} \Rightarrow \\
& \dot{\mu}=\mu\left(\delta_{g}+\rho\right)-\lambda F_{G} .
\end{aligned}
$$

along with the equations of motion (2) and (3). 
Taking the time derivative of $(40)$, solving for $\dot{C}$ and inserting 42, , 40, as well as using $\eta=-U_{C C} C / U_{C}$, leads to the Keynes-Ramsey rule (4). A similar derivation with respect to $\mu$ yields (5).

Decentralised solution We define $B_{t}$ as the balance of payments related to land ownership (the difference between land rents and the cost (revenue) of buying (selling) land at price $\left.p_{t}\right), B_{t}=\left(1-\tau_{t}^{l r}\right) l_{t} L-p_{t} \dot{L}-\tau_{t}^{l v} p_{t} L$. The representative household's maximisation problem then becomes

$$
\begin{array}{ll} 
& \max _{C_{t}, B_{L}} \int_{t=0}^{\infty} U\left(C_{t}\right) e^{-\rho t} d t \\
\text { s.t. } & \dot{K}_{t}=r_{t} K_{t}+B_{t}-C_{t} \\
& \dot{L}=\frac{1}{p_{t}}\left(\left(1-\tau_{t}^{l r}\right) l_{t} L-\tau_{t}^{l v} p_{t} L-B_{t}\right) .
\end{array}
$$

As above, we write $\lambda$ and $\mu$ for the multipliers of (44) and (45) in the current value Hamiltonian $H$ to derive the first order conditions and equations of motion,

$$
\begin{aligned}
\frac{\partial H}{\partial C} & =U_{C}-\lambda=0 \\
\frac{\partial H}{\partial B} & =\lambda-\frac{1}{p} \mu=0 \\
\dot{\lambda} & =\lambda(\rho-r) \\
\dot{\mu} & =\mu\left(\rho-\left(1-\tau^{l r}\right) \frac{l}{p}+\tau^{l v}\right) .
\end{aligned}
$$

Using equation (47) and its time derivative to replace $\mu$ and $\dot{\mu}$ in equation 49, then inserting equation (48), we obtain (dropping the $t$ subscripts):

$$
\rho-\left(1-\tau^{l r}\right) \frac{l}{p}+\tau^{l v}=\frac{\dot{\mu}}{\mu}=\frac{\dot{p}}{p}+\frac{\dot{\lambda}}{\lambda}=\frac{\dot{p}}{p}+\rho-r
$$

Reordered, this gives the common rate of return $r$ for both assets

$$
r=\left(1-\tau^{l r}\right) \frac{l}{p}+\frac{\dot{p}}{p}-\tau^{l v} .
$$

